2019 Global Fashion Management Conference at Paris Proceedings: 534-535 (July 2019) https://doi.org/10.15444/GFMC2019.05.06.07

\title{
EXPLORING THE REWARDS DIMENSION OF ENGAGEMENT IN CONSUMER-FASHION BRAND RELATIONSHIP
}

\author{
Maria Gonçalves Cabaço, Instituto Universitário de Lisboa (ISCTE-IUL), Portugal \\ Ricardo Godinho Bilro, Instituto Universitário de Lisboa (ISCTE-IUL) and Business \\ Research Unit (BRU/UNIDE), Portugal ${ }^{1}$ \\ Sandra Maria Correia Loureiro, Instituto Universitário de Lisboa (ISCTE-IUL) and \\ Business Research Unit (BRU/UNIDE), Portugal
}

\begin{abstract}
The current research aims to explore the role of hedonic rewards (Babin, Darden \& Griffin, 1994) in the relationship between consumers and fashion brands, specifically through brand engagement within online fashion brand communities. In this sense, we set out an analysis of several engagement dimensions based on previous literature (Baldus, Voorhees, $\&$ Calantone, 2015), with the purpose of exploring the role of brand engagement between consumers and the online fashion brand communities they are engaged with. To do so, we have performed a Netnography analysis (Kozinets, 2002), based on the interactions of consumers and a well-known online brand community.
\end{abstract}

We collect the data from an online fashion brand community - Beauty Insider (https://www.sephora.com/community) -, from the well-known cosmetics brand Sephora. This online community was launched in August 2017 and is considered an examples of a brilliant brand communities that is shaping the online environment (Marketing Insider Group, 2017). To perform our study, we decide to analyses the content of this online fashion brand community through a text-mining technique. This technique is capable to extract, examine, and transpose the vast amount of users' interactions on these online brand communities into valuable insights (Fan, Wallace \& Zhang, 2006). This technique is a solid and confirmed approach, already validated and tested by several authors (e.g., Bilro, Loureiro e Guerreiro 2018; Cai \& Qu, 2018; Jeon, Lee, \& Jeong, 2018; Tang \& Guo, 2015). Concerning our method, we collect a sample of 1,090 consumer reviews made available between April $20^{\text {th }}$ and May $11^{\text {th }}, 2018$. All the reviews are from consumers of USA. We began by classifying the topics most covered in these sample reviews. The text-mining tool identified 142 topics. The six topics more relevant (by relevance) extracted by the tool were 'Nickname', 'Product', 'Person', 'Body Parts', 'Industrial Company' and 'Organization'. We should note that for each review we may find several topics. This analysis is possible due to the use of NLP - Natural Language Processing - which relates the various dimensions or variables to existing topics (Fan et al., 2006; Mostafa, 2013).

We then performed a topic sentiment analysis. Of the topics reported, the text-mining tool extracted 8,888 sentiment topics, of which 2,520 are related to interactions between members of the Online Community. The dimension that arises most from the analysis of

${ }^{1}$ bilro.ricardo@gmail.com 
feelings made is 'Community members interaction', that is, the interaction between members or users of online community Beauty Insider. On the opposite, the topic 'Body Part' is the one with the lowest value. It should be also noted that none of the topics or constructs has a negative sentimental value.

Based on this study, it was possible to undertake some preliminary findings. Firstly, we may assume that online fashion brand communities allow consumers to have an up-to-date and reliable information about the brand they are associated with, and that they understand this type of platform as a great way to keep up-to-date on the brand associated with the online community they participate. Secondly, managers and marketers should be able to provide experiences to consumers, based on real opinions. A fashion brand and/or fashion company that involves its consumers will be a successful brand, and its consumers may experience their desires, needs and expectations satisfied.

Keywords: conspicuous consumption, recession, international, survey

\section{References}

Babin, Barry J., Darden, William R., \& Griffin, Mitch. (1994). Work and/or fun: Measuring hedonic and utilitarian shopping value. Journal of Consumer Research, $20,644-656$.

Baldus, B. J., Voorhees, C., \& Calantone, R. (2015). Online brand community engagement: Scale development and validation. Journal of Business Research, 68(5), 978-985.

Bilro, R. G., Loureiro, S. M. C., \& Guerreiro, J. (2018). Exploring online customer engagement with hospitality products and its relationship with involvement, emotional states, experience and brand advocacy, Journal of Hospitality Marketing \& Management, 28(2), 147-171.

Cai, R., \& Qu, H. (2018). Customers' perceived justice, emotions, direct and indirect reactions to service recovery: Moderating effects of recovery efforts. Journal of Hospitality Marketing \& Management, 27(3), 323-345.

Fan, W., Wallace, L., Rich, S., \& Zhang, Z. 2006. Tapping the Power of Text Mining. Communications of the AC, 49(9), 77-82.

Jeon, M. M., Lee, S., \& Jeong, M. (2018). e-Social Influence and Customers' Behavioral Intentions on a Bed and Breakfast Website. Journal of Hospitality Marketing \& Management, 27(3), 366-385.

Kozinets, R. V. (2002). The Field Behind the Screen: Using Netnography for Marketing Research in Online Communities. Journal of Marketing Research, 39(1), 61-72.

Marketing Insider Group. (2017). 5 Examples of Brilliant Brand Communities That Are Shaping The Online World | Marketing Insider Group. Retrieved November 21, 2018, from https://marketinginsidergroup.com/content-marketing/5-examplesbrilliant-brand-communities-shaping-online-world/

Mostafa, M. M. (2013). More than words: Social networks' text mining for consumer brand sentiments. Expert Systems with Applications, 40(10), 4241-4251.

Tang, C., \& Guo, L. (2015). Digging for gold with a simple tool: Validating text mining in studying electronic word-of-mouth (eWOM) communication. Marketing Letters, 26(1), 67-80. 